\title{
Using Online Technologies to Extend a Classroom to Learners at a Distance
}

\author{
Charles R. Graham \\ charles.graham@byu.edu \\ John L. Hilton III \\ johnhiltoniii@byu.edu \\ Peter Rich \\ pjrich@gmail.com \\ David Wiley \\ david.wiley@gmail.com
}

Follow this and additional works at: https://scholarsarchive.byu.edu/facpub

Part of the Educational Psychology Commons

\section{Original Publication Citation}

C. R. Graham, J. Hilton, P. Rich, D. Wiley, (21). "Using Online Technologies to Extend a Classroom to Learners at a Distance," Distance Education 31(1), pp. 77-92

\section{BYU ScholarsArchive Citation}

Graham, Charles R.; Hilton, John L. III; Rich, Peter; and Wiley, David, "Using Online Technologies to Extend a Classroom to Learners at a Distance" (2010). Faculty Publications. 104.

https://scholarsarchive.byu.edu/facpub/104

This Peer-Reviewed Article is brought to you for free and open access by BYU ScholarsArchive. It has been accepted for inclusion in Faculty Publications by an authorized administrator of BYU ScholarsArchive. For more information, please contact ellen_amatangelo@byu.edu. 
Running head: USING ONLINE TECHNOLOGIES

Using Online Technologies to Extend a Classroom to Learners at a Distance

John L. Hilton III, Brigham Young University

Charles Graham, Brigham Young University

Peter Rich, Brigham Young University

David Wiley, Brigham Young University

John Hilton is the corresponding author. His phone number is $801-318-5521$, and email address is johnhiltoniii@byu.edu. 


\begin{abstract}
The authors studied a course in which an instructor allowed individuals at a distance to participate. These students, though not formally enrolled in the university where the class took place, were given full access to all course materials and were encouraged to complete course assignments. The authors examined the time and technical proficiency required to involve learners at a distance. These learners were surveyed to determine how they perceived the course. Their work in the course was also examined. Learners at a distance reported receiving some benefit from the course, particularly in terms of learnercontent interaction. Students in the face-to-face classroom were surveyed as to whether students participating at a distance affected their perception of the course and said there was no impact. The implications and limitations of these results are discussed.
\end{abstract}

Key words: open education, distance learning, technology in the classroom, 
Using Online Technologies to Extend a Classroom to Learners at a Distance

Suppose Professor Smith teaches in a face-to-face setting. She would like to invite learners at a distance to participate in her courses free of charge, believing that this could enrich both these learners as well as her own face-toface students. She knows that a few decades ago it would have been timeconsuming and expensive to share her course with learners at a distance, and she does not have a lot of time to invest in this idea. However, Professor Smith wonders if she could use current online technologies to invite these learners to participate in her course with minimal effort. If she can, is it feasible only to share the course content, or could other interactions take place? What effect (if any) would learners at a distance have on her face-to-face students? The purpose of this paper is to address these questions.

A few educators are beginning to use online technologies to share their courses with others. Young (2008) reported on a course taught by David Wiley in which Wiley opened his course to participants around the world. Some of the participants in this class were students enrolled at the university where he taught, others participated from a distance. All of the course readings and assignments were freely available via the Internet. Learners at a distance were able to turn in work and receive feedback from Wiley. Although learners who enrolled in the class from a distance were not formally enrolled in the university, and were not given course credit, Wiley gave unofficial certificates of completion to students who finished the course. The course had such a large impact on a group of 
students from Italy that they published a paper about their experience in the course (Fini et al., 2008).

In teaching this course Wiley was able to facilitate the three interactions (learner-content, learner-learner, and learner-instructor) described by Moore (1989). Although historically, learner-content interactions have been the basis of distance education (Williams, Nicholas, \& Gunter, 2005), technological advances have made learner-learner and learner-instructor interactions increasingly accessible to those at a distance (Anderson and Garrison, 1998).

In the course described above, Wiley deliberately encouraged learnerlearner interactions between both face-to-face and distance learners. He also personally engaged with learners at a distance. Students in the course reported benefiting from these interactions (Fini et al., 2008).

\section{Review of Literature}

Wiley is not alone attempting create interactions with "unofficial" learners at a distance. The OpenCourseWare (OCW) movement in general aims to extend course materials to learners regardless of their enrollment in a university. Amongst these institutions, perhaps the single most well-known program is MIT's OpenCourseWare, which provides open access to materials used to teach over 1,900 courses (http://ocw.mit.edu/). One can find a growing list of higher education institutions participating in the creation of OER by visiting the OpenCourseware Consortium (http://www.ocwconsortium.org). As of November 2009 there were 196 members worldwide (OpenCourseWare Consortium, 2009). 
Some institutions, instead of offering full courses, offer small units of instruction such as a class module, video file, or lesson plan. And universities are the only ones offering open educational resources (Wiley, Gurrell, 2009). Individual teachers also upload video or audio versions of lectures to YouTube or iTunes, post PowerPoint presentations to SlideShare, and share OER in a variety of other ways (Gurrell, 2008).

Ketterl, Mertens, and Morisse (2006) point out that iTunes University is a place where university lectures can be placed for students to access. This trend of making educational resources available is extending to many different areas. For example, several publishers are finding ways to make electronic textbooks available for free (Matkin, 2009). Some of these textbooks are part of noncommercial enterprises like Rice University's Connexions initiative (Baker, et al, 2009). Similarly, Wikibooks, modeled after Wikipedia, is intended to allow a collaborative approach to textbook creation. As of March 2009, 35,049 pages of text had been created in the Wikibooks website. Other textbooks are part of forprofit enterprises, like those published by Flat World Knowledge.

Blackall (n.d), taught a course called "Flexible Learning" in which individuals from around the world were invited to participate free of charge. Students at a distance were able to interact with course content, other learners and the instructor.

Downes and Siemens taught what they called a "Massively Open Online Course" in which 2,400 people enrolled (Siemens, 2008). The overwhelming majority of these students were not registered for credit through a university. This 
course used several technologies, including blogs, Second Life, Page Flakes, UStream and Elluminate sessions, and discussion forums to facilitate interactions between learners, content and the instructors (Siemens and Downes, n.d.). All three types of interactions were high; however, this interaction did not come without a price. This course required a massive investment on the time of the instructors who spent about twenty hours each week facilitating the course (Siemens, 2008). Fini (2009) provides a careful review of the technologies offered by Siemens and Downes and how participants made use of these technologies.

These classes clearly demonstrate that online technologies can be used not only to share course content with the non-enrolled public but also to facilitate learner-learner and learner-instructor interactions in this group. However, these courses also demonstrate that a significant investment of time may be necessary to open a class to learners at a distance, particularly for instructors who wish to facilitate learner-learner and learner-instructor interactions.

The present study is an investigation of the extent to which a face-to-face course can be shared with learners at a distance without putting undue strain on the instructor. We examined the course "Introduction to Open Education" taught by Wiley in the winter of 2009. Because learner-instructor interactions are the most difficult to scale (Anderson, 2004), the focus of this course was to establish learner-content and learner-learner interactions. This version of the open sharing of the course was intentionally a minimalist, in which Wiley spent little time outside of normal class preparation in facilitating the learning of those unofficial 
learners at a distance. Our purpose was to learn first the amount of time and technical proficiency necessary to extend one's course to learners at a distance, and second to see if learner-content and learner-learner interactions could be accomplished with minimal effort on the part of the instructor.

We first describe the course itself, then discuss the time and technologies used by Wiley in the creation of his course, and finally examine the uses that learners at a distance made of the course and how opening the course affected students in the face-to- face setting.

About Introduction to Open Education 2009

This course was a graduate seminar for Education students. In an earlier version of "Introduction to Open Education," Wiley (2007) explained that "The goals of the course are (1) to give you a firm grounding in the current state of the field of open education, including related topics like copyright, licensing, and sustainability, (2) to help you locate open education in the context of mainstream instructional technologies like learning objects, and (3) to get you thinking, writing, and dialoguing creatively and critically about current practices and possible alternative practices in open education."

Like the class described by Young (2008), all of the course readings came from materials openly available online. Wiley recorded class lectures and also posted these online. Thus, all of the content was freely available to participants at a distance. Forty-two individuals from eleven different countries enrolled; all were invited to complete course assignments and receive feedback from Wiley. 
Unlike the course described by Young, as well as some instantiations of this kind of course, Wiley spent little time actively encouraging the participation of members at a distance. Although he corresponded with members enrolled at a distance and provided feedback on their work, this version of the course took a minimalist approach, in which the additional amount of Wiley's time necessary to keep the course open was kept to less than thirty minutes each week. This was an important part of the approach, recognizing that many people who want to open up a course to others will not be able to dedicate a significant amount of time to supporting learners at a distance.

\section{Method}

\section{Participants}

Wiley, the instructor of the course, was invited to share his insights into the course he taught. All of the learners at a distance who provided email addresses (38 participants), as well as the six face-to-face students were invited to participate in this study. Because learners at a distance were not required to share any information other than their name to sign up for the course, the age, educational level, and other demographic information about these participants is unknown. The face-to-face students consisted of five doctoral students and one student seeking a masters degree. Four were male, two were female, and they ranged in age from 25-40.

Instrumentation

Two brief questionnaires were constructed for this study, one for learners at a distance and the other for students in the face-to-face class (see appendices 
$A$ and $B)$. The surveys were identical except for two additional questions given to face-to-face students to ascertain how having learners at a distance influenced their experience in the course. The other survey questions were designed to gauge how much time students put into the course, as well as which aspects of the course they considered to be useful.

\section{Procedures}

Class members were sent an email inviting them to answer the brief online questionnaire described above. Participants were sent a reminder email after one week.

Another approach to determining what uses learners at a distance made of the course was to examine their work on the course. This was accomplished by looking at the blogs of these students and counting the number of posts they made that were connected with the course.

Results: Time and Technologies Necessary to Create This Course

The officially supported learning management system at Wiley's institution at the time the course was offered was Blackboard. Wiley made a specific choice to avoid this system because there was no way to offer broader invitations to students to participate in a Blackboard-hosted course. The Blackboard system is designed in a way that prevents anyone who has not registered for the course from accessing any of the course materials or discussions. Wiley also chose to avoid Blackboard because even paying students who formally register for a course loose all access to course materials and discussions when the semester ends. 
The main tool Wiley used in creating the space for his course was Wordpress. Wordpress is a free online tool that can be used to create blogs or websites. Using this tool he was able to create a course website that looked professional in one hour (see Figure 1).

Course announcements, assignments, and the syllabus were posted on the Wordpress site. Because Wiley had already created these materials for his face-to-face learners the additional amount of time needed to share them with learners at a distance was minimal. Links to course readings were also available on the site.

In addition to using Wordpress, Wiley created a wiki in order to facilitate student participation in the course. Wiley wanted a separate place where students could add content to an unofficial course site. He created a wiki to facilitate this student participation, and provided a link from the official Wordpress site to the wiki. Figure 2 is a screenshot of this wiki.

Students used the wiki to enroll in the course, by inputting their name, email address and blog site. Students were responsible to create their own blog if they did not have one, as all student work was to be posted on blogs to make it easier for others in the class to see and engage their work. In addition to registering for the course via the wiki, students could use the wiki to suggest alternate assignments and to organize themselves into groups.

Wiley used his own pre-existing Wiki for this course; however, he said that by using a site such as http://pbwiki.com that a course wiki similar to the one he used could be created in less than one hour. 
Wiley used a software program called Profcast (the only tool used that was not free) to record his lectures and publish them to both blip.tv and iTunes. Profcast allowed him to record his audio explanations as well as the slides to create an audiovisual presentation (see figures 3 and 4). As of April 2009, an academic version of Profcast was available for 40 U.S. dollars.

Wiley reported that this was his first time uploading content to blip.tv and iTunes, and that it took about fifteen minutes and basic computer skills to set up these channels. Once the channels were created, uploading each lecture into blip.tv and iTunes took five minutes.

Thus the components of the course were available through Wordpress (course website), a wiki (course participation), student blogs (posting homework assignments and discussion) and Profcast, blip.tv, and iTunes (lecture material). While Wiley was free to use any tools he chose in supplementing his course, no support was provided for these tools by the university. Ample support was available, however, from the online communities of users of these tools. It must be noted that Wiley's estimates of the time necessary to create these course components are from one who has a high level of technical proficiency. One of the authors of the present study, having significantly less technical expertise than Wiley found that to set up these course components took approximately fifteen hours. This may be a more realistic figure for those inexperienced with creating Wordpress sites or wikis. Nevertheless, ten years ago it would have been both financially and technically prohibitive to create a course that could be shared with learners at a distance. However, the use of a 
few free or inexpensive tools can now create the spaces necessary to extend one's classroom to participants around the world.

Results: Participation by learners studying at a distance and its effect on students in the face-to-face setting.

Survey Results from Learners at a Distance

Of the 42 members of the course who participated at a distance, 38 posted their email addresses. All of these individuals received an email inviting them to participate in a survey about their participation in the course. Eleven individuals responded to the survey (29\% response rate).

Nine of the eleven respondents indicated that they had put at least eight hours into the course, with an average of 15.5 hours spent on the course per individual. The other two survey respondents said that due to time pressures they did not spend any time on the course.

Table 1 summarizes how students ranked the usefulness of various aspects of the course.

Thus, as ranked by the participants the most helpful activities were completing course readings, writing and reading blog posts, and watching lectures on blip.tv. The least used activities were communication with the instructor and listening to lectures via iTunes.

In order to more fully compare the various course aspects, the rankings of those who did not use a particular aspect of the course were omitted and the levels of usefulness were compared a second time. Table 2 summarizes the 
mean responses of participants (the rating scale was $1=$ very useful, $4=$ not useful).

Thus, when those who did not use a particular aspect of the course were excluded each course aspect was considered somewhat or very useful by a majority of respondents. Responses to the question, "What could have been done to make this course a better experience for you?" fell primarily into three categories. These were comments about (1) the clarity of how to progress in the course, (2) increasing interaction and (3) a lack of time to take the course.

Four of the ten people who answered this question focused on their uncertainty about how to progress in the course. For example, one participant said, "The timeline of the course was somewhat confusing." Another said, "[I] have lacked information on the progress of the course."

Three of the ten people who answered this question focused on increasing interaction both amongst students and between students and the professor. One participant suggests doing live streams of classroom session so that those who were at a distance could feel more a part of the class. Another participant said, "I ended my participation after the initial set of assignment...More interaction with the instructor and 'on campus' students might have been helpful. A seminar or workshop version of this course (less than a 3-credit, full semester) would have been more appealing as well."

The idea of having a seminar version of the course seems related to a third theme in the comments, that some participants simply did not have time to make the course a good experience. One participant said, "I liked it. Any 
shortcomings were entirely my own." Another indicated, that nothing could have been done by Wiley to improve the course saying, "From my end [I needed] more time to work on the course but it just couldn't be done at this point in my life."

\section{Examination of student work}

Of the 42 members of the course who participated at a distance, 27 posted information about their blogs. Table 3 summarizes the analysis of these blogs. Out of 27 total participants who listed blog information, twelve participants made a total of 39 posts.

These blog postings varied in depth. Some of them simply announced that the individual had decided to participate in the course. For example, one participant wrote, "I am currently enrolled as a participant in IPT 692R: Introduction to Open Education, offered by BYU online and free to anyone who wants the experience. I am looking forward to... learning more about open education. I currently work as an instructional designer and project manager for online course development projects in higher education" (Venable, 2009). This participant also contributed two other posts as part of her coursework.

Other posts were quite extensive. For example, as part of one assignment Capdet (2009), who sometimes blogged in Spanish, created a mind map to visually illustrate what she had learned about the sustainability of open education (see figure 5). This blog post was judged by Wiley to be among some of the best produced in the course.

Some of the participants received comments on their blog posts, thus facilitating learner-learner and learner-instructor interaction. Browne (2009) 
responded to a class lecture by creating an extensive blog post on the different types of Creative Commons Licenses. As of March 2009, eight comments had been made on this post, including posts by three students as well as posts from Wiley.

From an analysis of the blogs, it appears that one out of every six individuals who enrolled at a distance made more than one blog post for Wiley's course. Thus while the blog analysis does not present a convincing argument that students at a distance wrote extensively about the course, it appears that some students did work for the course.

It also should be noted that an examination of student work cannot give the full account of what has been learned. Renee wrote of her experience participating in the Downes and Siemens course mentioned previously, saying "I consider myself to be a silent observer...I started a daily blog, but quickly abandoned it because I wasn't sure what I was thinking. I will take it back up again when I feel comfortable with my position. I find the dialog fascinating and will continue to read the daily, follow the links, investigate the blogs, etc. But don't count me out just because you haven't heard my voice!" (Siemens \& Downes, 2008). Thus, a lack of posts on the course on an individual's blog does not necessarily indicate disengagement with the course.

Survey Results from Face-to-Face Students

The primary purpose of surveying the face-to-face students was to determine whether having learners participating at a distance affected their experience in the class. Of the six students enrolled in the face-to-face version of 
the class five completed the survey, for a response rate of $83 \%$. All five answered the question, "How did having students participating at a distance affect your experience in the class?" by selecting the option, "made no difference." Participants were invited to share the reason why they answered that question the way that they did. The following response from a participant was typical: "I had very little contact with them-really wasn't even aware that they were there after the first week or so. There were a couple blogs that I kept up with, but those dropped off after a few weeks as well."

From the perspective of a teacher trying to enhance learner-learner interactions this may have been a disappointing outcome. When Wiley was asked to share his perspective on the lack of influence learners at a distance had on the face-to-face students he said, "It's quite a natural response. Honestly, in this version of the course I made almost no effort to connect the distance learners with the on-campus students because I wanted to see if and how they might self-organize. In past versions of the course when I have invested a little more effort to facilitate interactions between face-to-face and distance students, learners at a distance have made a huge impact on the learning experiences of those in the face-to-face setting."

\section{Discussion}

The fact that "course readings" was the activity that was rated as most useful by learners at a distance suggests that the learner-content interaction is certainly important. The second highest rated learning activity (writing blog posts) also falls in the category of learner-content interaction. 
However, the fact that students rated the learner-content interactions as more useful than other interactions does not necessarily indicate that students place a higher value on this form of interaction. It may be that had the learnerlearner or learner-instructor components of the course been stronger that these interactions have been rated as high or higher than the learner-content interaction.

The way in which participants viewed the learner-learner interaction was somewhat mixed. Reading blog posts by other members was considered "very useful" by a third of the participants at a distance and "somewhat useful" by another third. Although a majority of learners at a distance said that making comments on peers' blogs or receiving comments from peers on their blogs was either somewhat or very useful, more than a third of students at a distance did not use this aspect of the course. Students in the face-to-face setting saw no increased learner-learner interactions as a result of having learners studying with them at a distance.

As stated earlier, Wiley hoped that students would self-organize to create strong learner-learner interactions. In this instance, when the instructor invested almost no time facilitating learner-learner interactions, these interactions were not strong. The only effort made by the instructor to facilitate this self-organization was designating a section in the course wiki for students to add their names, contact information, and blog address. With this information, official on-campus students and informal off-campus students could find and interact with each other. In a previous iteration of the course (described by Fini (2008)) Wiley took 
additional measures to help students self-organize, including creating and distributing an OPML file of all the course member blog feeds (allowing for easier reading of all course member writings) and highlighting both formal and informal student writing on the course blog to encourage connections between students. In the class described by Fini (2008), on-campus students benefitted from the participation of the learners at a distance in that they gained access to a wide breadth of perspectives on issues discussed in the class. While the on-campus class was comprised of Caucasian American and Asian students, informal participants included individuals from South Africa, Spain, Italy, the UK, Greece, Canada, and Iceland. The present study indicates that these benefits are more likely to be received when effort is made by the teacher to connect the on campus and distance students.

In total, eleven learners at a distance reported spending 121 hours on the course. Thirty-nine blog posts were written and several lectures were watched by learners at a distance. Although it is impossible to know if this effort would have been expended had the course not been freely available, we believe that a significant amount of this effort took place because of the course.

Limitations and Directions for Future Research

An obvious limitation of the present study is that it focuses on a single case and its results cannot necessarily be generalized. This class represented the first time Wiley attempted to facilitate an open education course using the model of limited instructor involvement with those at a distance. Although the response rate of $29 \%$ is close to the acceptable range set forth by Sheehan 
(2001), it cannot be known whether those who responded to the request to participate in the survey are substantially different from students who chose not to participate. In fact, it seems likely that the two groups are different.

In the present study we found that an instructor could extend class content to learners at a distance at relatively little cost in time or money. Using mostly free software, Wiley was able to put class lectures and materials online for open access. Learners at a distance appeared to receive some benefit from the learner-content interactions provided by the course, and to a limited extent the learner-learner interactions. It may be that Wiley could have facilitated stronger learner-learner interactions had he encouraged students in this direction. Further research is needed to determine how much instructor time would be necessary to facilitate learner-learner interactions in this type of class. Wiley said, "In a future version of this course I think I would more frequently emphasize to students the importance of interacting with learners at a distance. I don't say this just for the sake of increasing interaction, but because I believe this type of interaction provides a tremendous value for those participating in the course. I believe that with a little more effort on my part to connect with learners at a distance I could have made the course a substantially better experience for them."

Many additional questions remain about the process of making an existing college class openly available to learners at a distance. For example, what benefits (if any) are accrued by the institution? What relationship should exist (if any) between off and on campus learners? To what extent should an instructor 
seek to increase benefits received by those learners not formally enrolled in the course?

The idea of opening one's classroom to "unofficial" learners participating at a distance has important implications for increasing learning. Thus, for Professor Smith a key takeaway of this study is that it seems feasible for one to create the technological spaces necessary to extend one's course content to learners at a distance. Whether it is possible to facilitate strong learner-learner interactions with minimal effort on the part of the instructor, and impact this might have on students in the face-to-face classroom remains to be determined. 


\section{References}

Anderson, T., and Garrison, D.R. (1998). Learning in a networked world: New roles and responsibilities. In C. Gibson (Ed.) Distance Learners in Higher Education. (p.129-144). Mahwah, NJ: Erlbaum.

Anderson, T. (2004). Getting the mix right again: An updated and theoretical rational for interaction. The International Review of Research in Open and Distance Learning, 4(2). Retrieved March 24, 2009 from http://www.irrodl.org/index.php/irrodl/article/view/149/708

Baker, J., Thierstein, J., Fletcher, K, Kaur, M., Emmons, J. (2009). Open Textbook Proof-of-Concept via Connexions. The International Review of Research in Open and Distance Learning. 10 (5). Retrieved January 5, 2010 from http://www.irrodl.org/index.php/irrodl/article/view/633.

Blackall, L. (n.d). "Flexible Learning." Retrieved February 27, 2009 from http://wikieducator.org/Flexible learning.

Browne, J. (2009). "Fixing David's Remixability Matrix." Retrieved April 3, 2009 from http://brownelearning.org/blog/?p=239

Capdet, D. (2009). "The sustainability of the open education movement." Retrieved April 3, 2009 from http://dolorscapdet.blogspot.com/2009/02/ipt692r-sustainability-ofopen.html

Fini, A., Formiconi, A., Giorni, A., Pirruccello, N. S., Spadavecchia, E., \& Zibordi, E. (2008). IntroOpenEd 2007: An experience on Open Education by a 
virtual community of teachers. Journal of e-Learning and Knowledge Society, 4 (1), 231- 239.

Fini, A. (2009). The Technological Dimension of a Massive Open Online Course: The Case of the CCK08 Course Tools. The International Review of Research in Open and Distance Learning. 10 (5). Retrieved January 5, 2010 from http://www.irrodl.org/index.php/irrodl/article/view/633.

Gurell, S. (2008). Open educational resources handbook for educators 1.0. Logan, UT: Center for Open and Sustainable Learning.

Ketterl, M. Mertens, R. Morisse, K. (2006). Alternative Content Distribution Channels for Mobile Devices. In: Hug, T., Lindner, M., Bruck, P.A. (Eds.), Micromedia \& e-Learning 2.0: Gaining the Big Picture. Proceedings of Microlearning Conference 2006, Innsbruck (Austria), pp. 119 - 130, Innsbruck University Press, 2006.

Matkin, G. (2009, March). Open learning: What do open textbooks tell us about the revolution in education? The Center for Studies in Higher Education, Research \& Occasional Paper Series 1.09. http://cshe.berkeley.edu/publications/docs/ROPs-Matkin-OpenLearning03-31-09.pdf (accessed April 23, 2009).

Moore, M. (1989). Three types of interaction. American Journal of Distance Education, 3(2), 1-6. 
OpenCourseWare Consortium (2009). "Consortium members." Retrieved November 14, 2009, from:

http://www.ocwconsortium.org/members/consortium-members.html.

Sheehan, K. B. (2001). E-mail survey response rates: A review. Journal of Computer-Mediated Communication, 6(2), 1-20.

Siemens, G. (2008). "Who Is Still Participating?"

Retrieved February 27, 2009 from

http://ltc.umanitoba.ca/connectivism/?p=182

Siemens, G. and Downes, S. (2008). "Connectivism \& Connective Knowledge." Retrieved February 27, 2009 from http://ltc.umanitoba.ca/connectivism/?p=182\#comments

Siemens, G. and Downes, S. (n.d.). "Connectivism." Retrieved March 24, 2009 from

http://tc.umanitoba.ca/wiki/Connectivism\#Course blog is available here

Venable, M. (2009). "OER." Retrieved April 3, 2009 from http://mvenable.wordpress.com/intro-to-open-ed/

Wiley, D., \& Gurrell, S. (2009). A decade of development. Open Learning: The Journal of Open and Distance Learning, 24(1), 11-21.

Wiley, D. (2007). "Intro Open Ed Syllabus." Retrieved February 27, 2009 from http://opencontent.org/wiki/index.php?title=Intro Open Ed Syllabus

Williams, P., Nicholas, D., \& Gunter, B. (2005). E-learning: what the literature tells us about distance education. Perspectives, 57(2), 109-122. 
Young, J. (2008, Oct. 3). When Professors Print Their Own Diplomas, Who Needs Universities? The Chronicle of Higher Education, p. A13. 


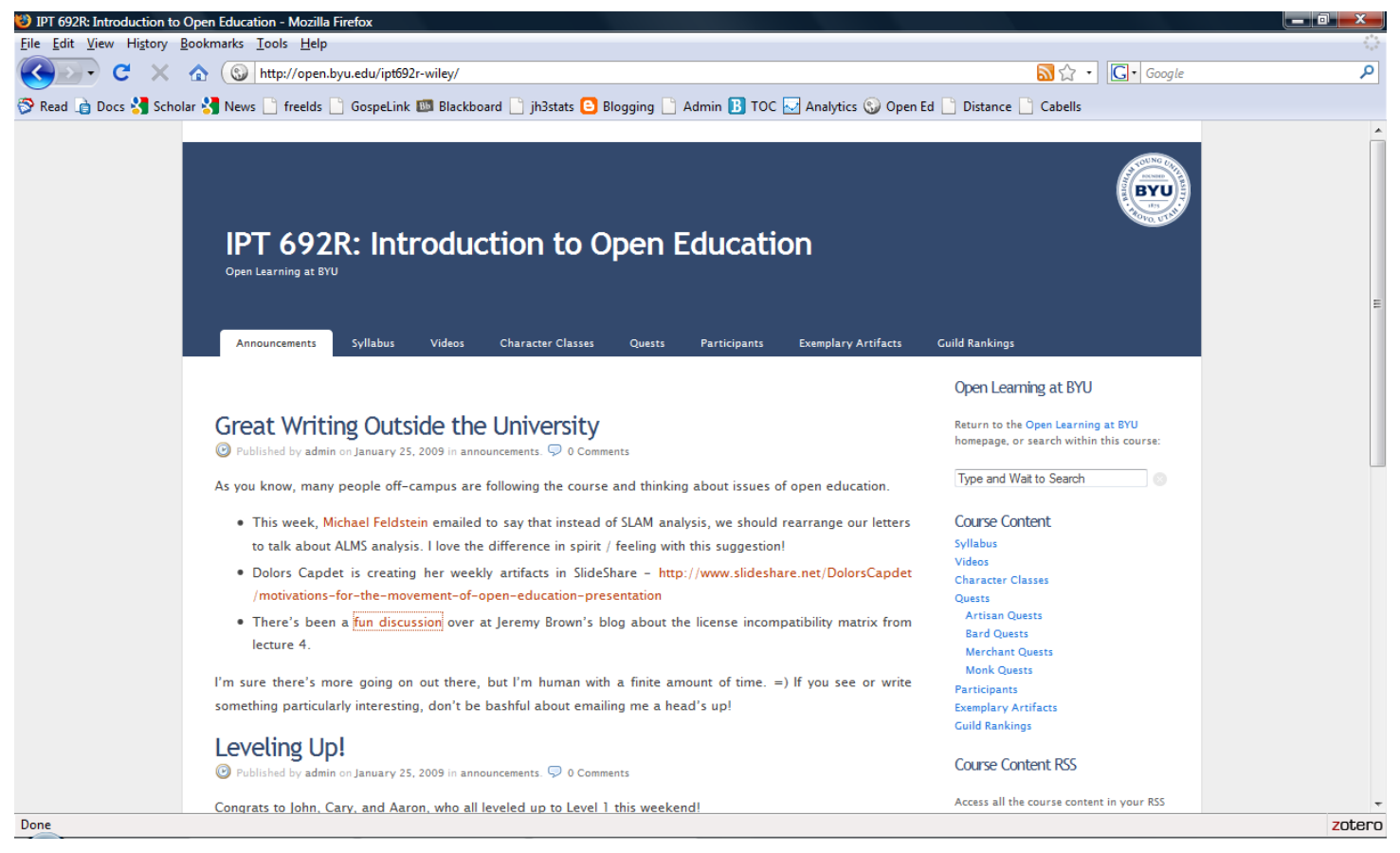

\section{Figure 1}

Wordpress site for Wiley's class 


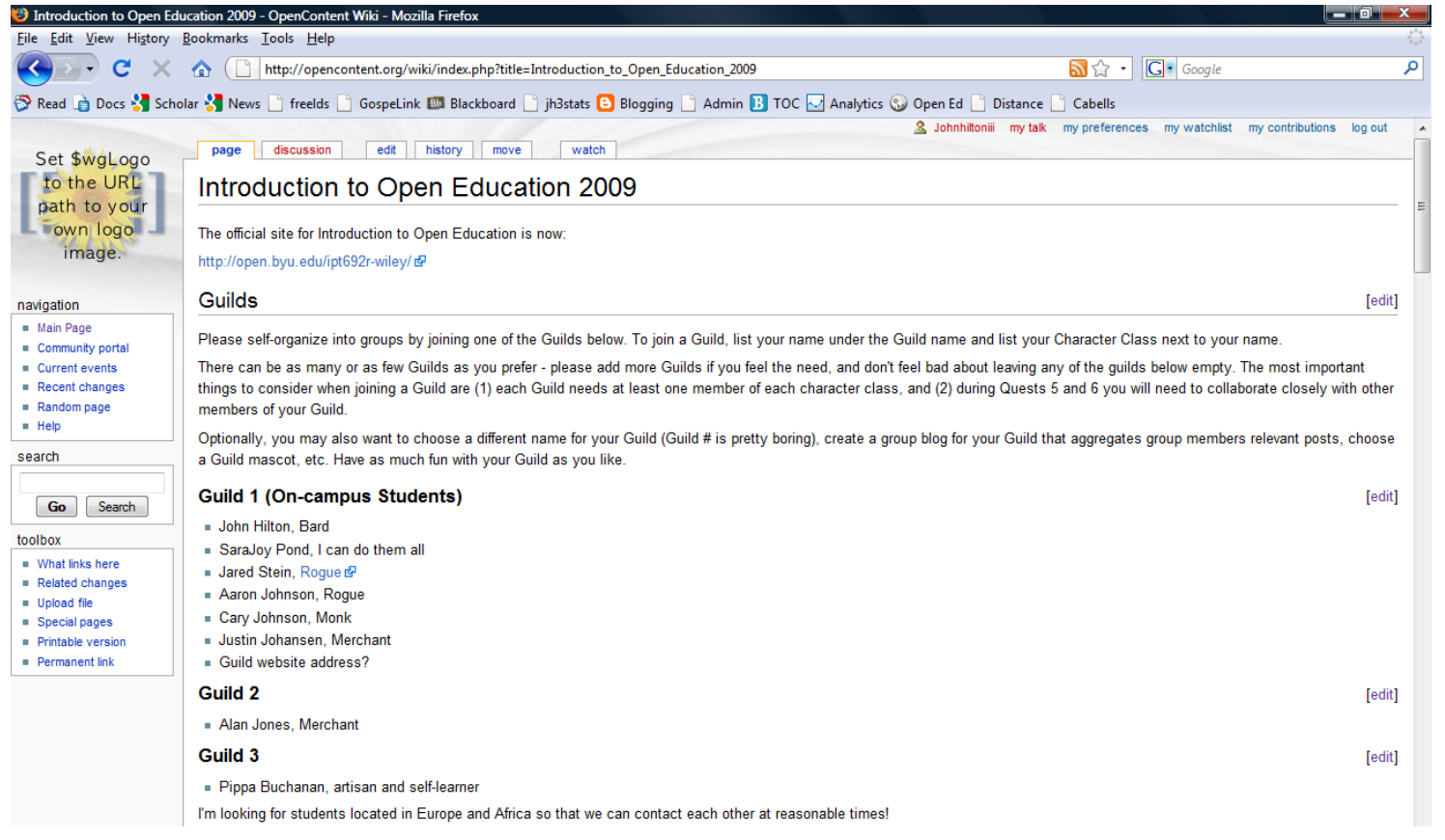

\section{Figure 2}

\section{Wiki site for Wiley's class}




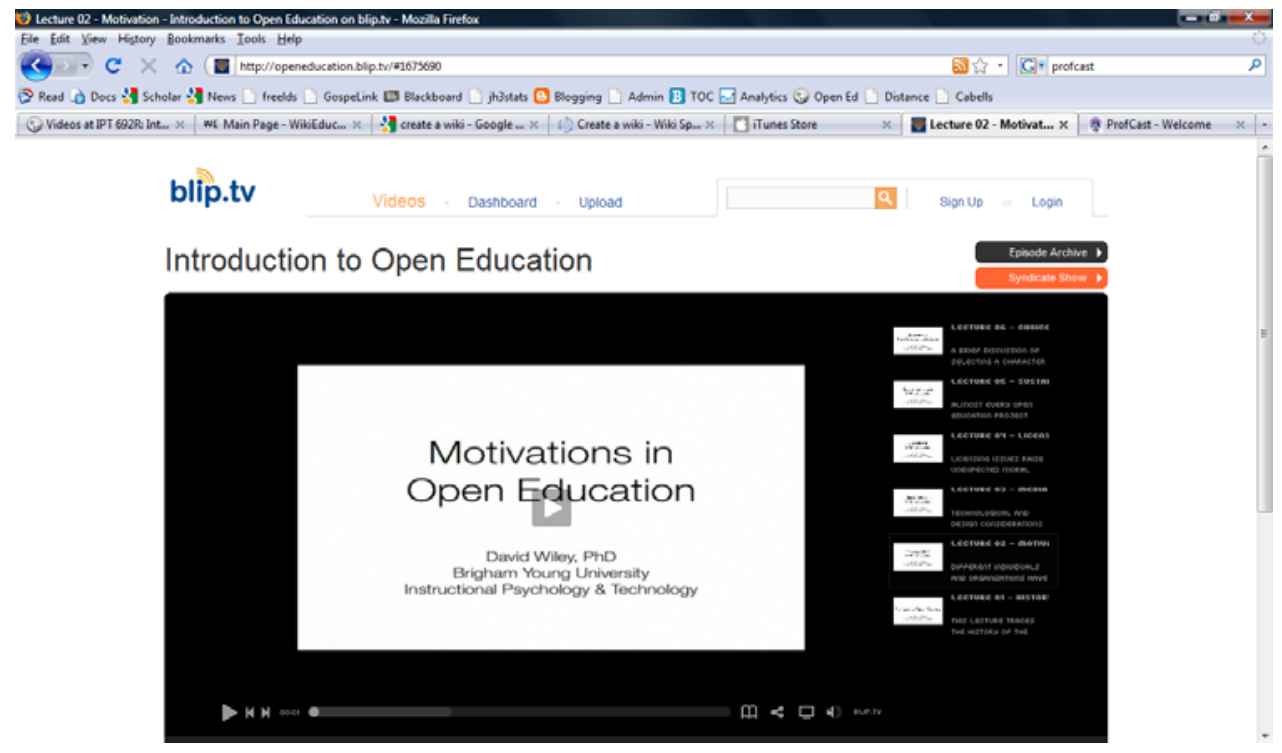

Figure 3

http://blip.tv page for Wiley's class 


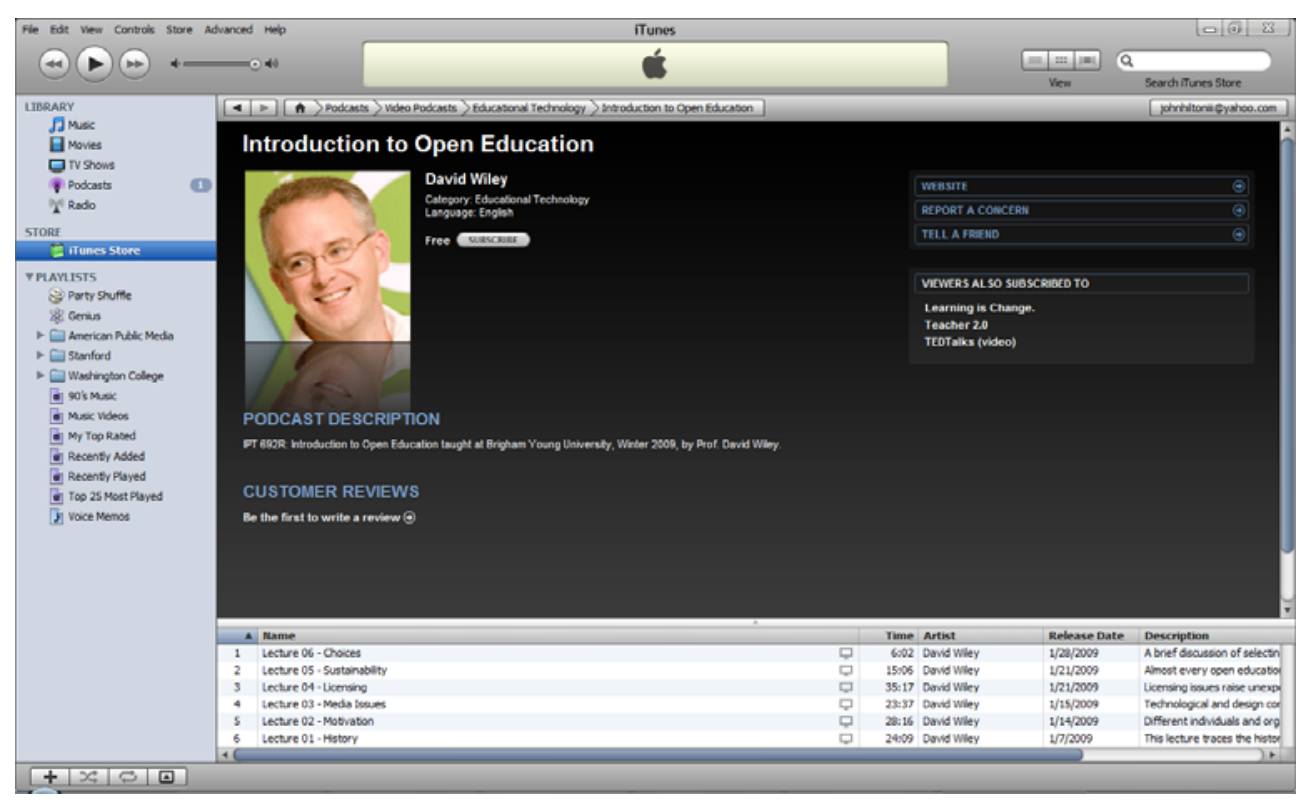

Figure 4

iTunes page for Wiley's class 


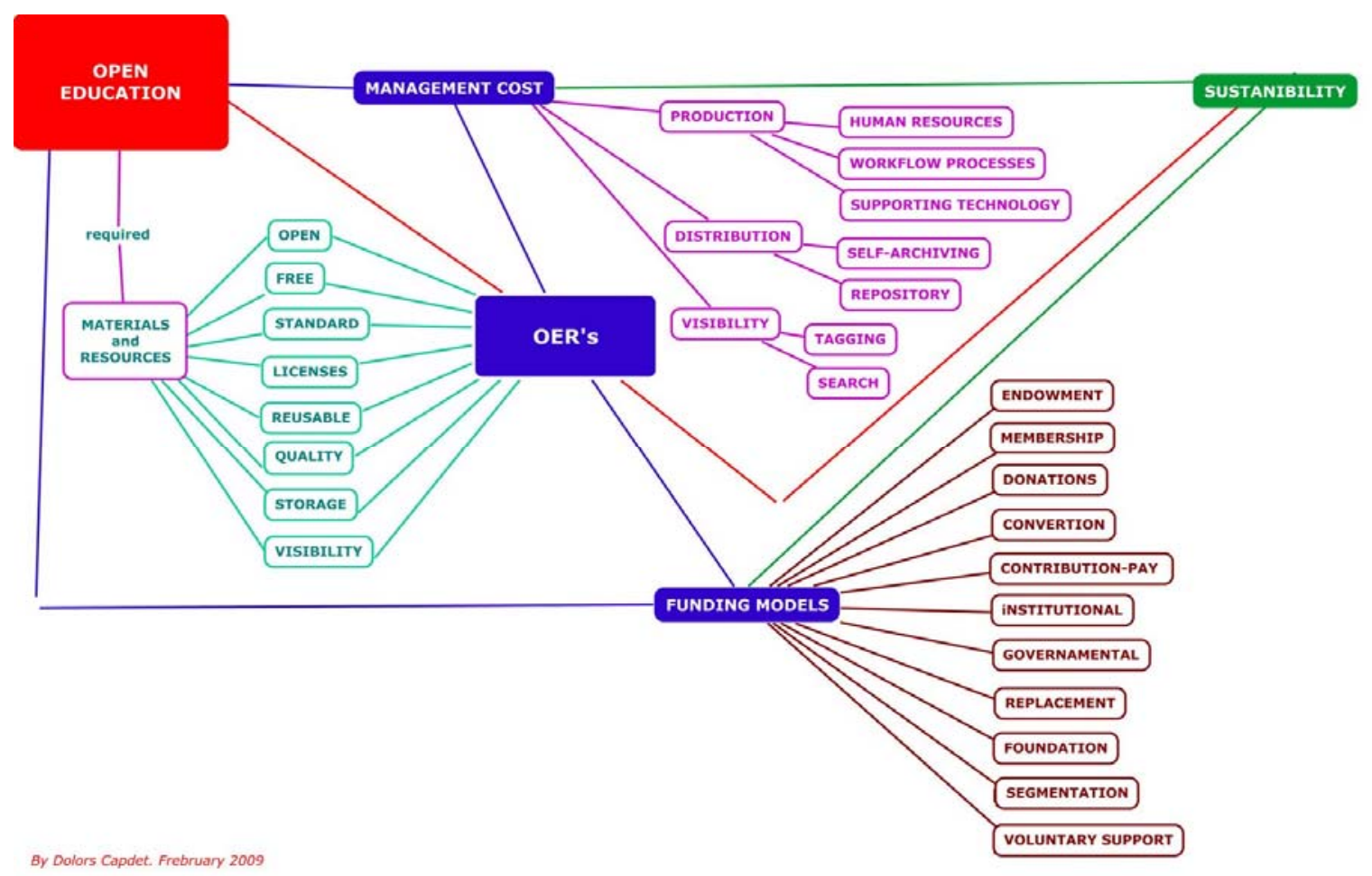

Figure 5

Blog post by a learner at a distance 
Table 1

Summary of how learners at a distance ranked course aspects

the activity as...

Number of students who ranked

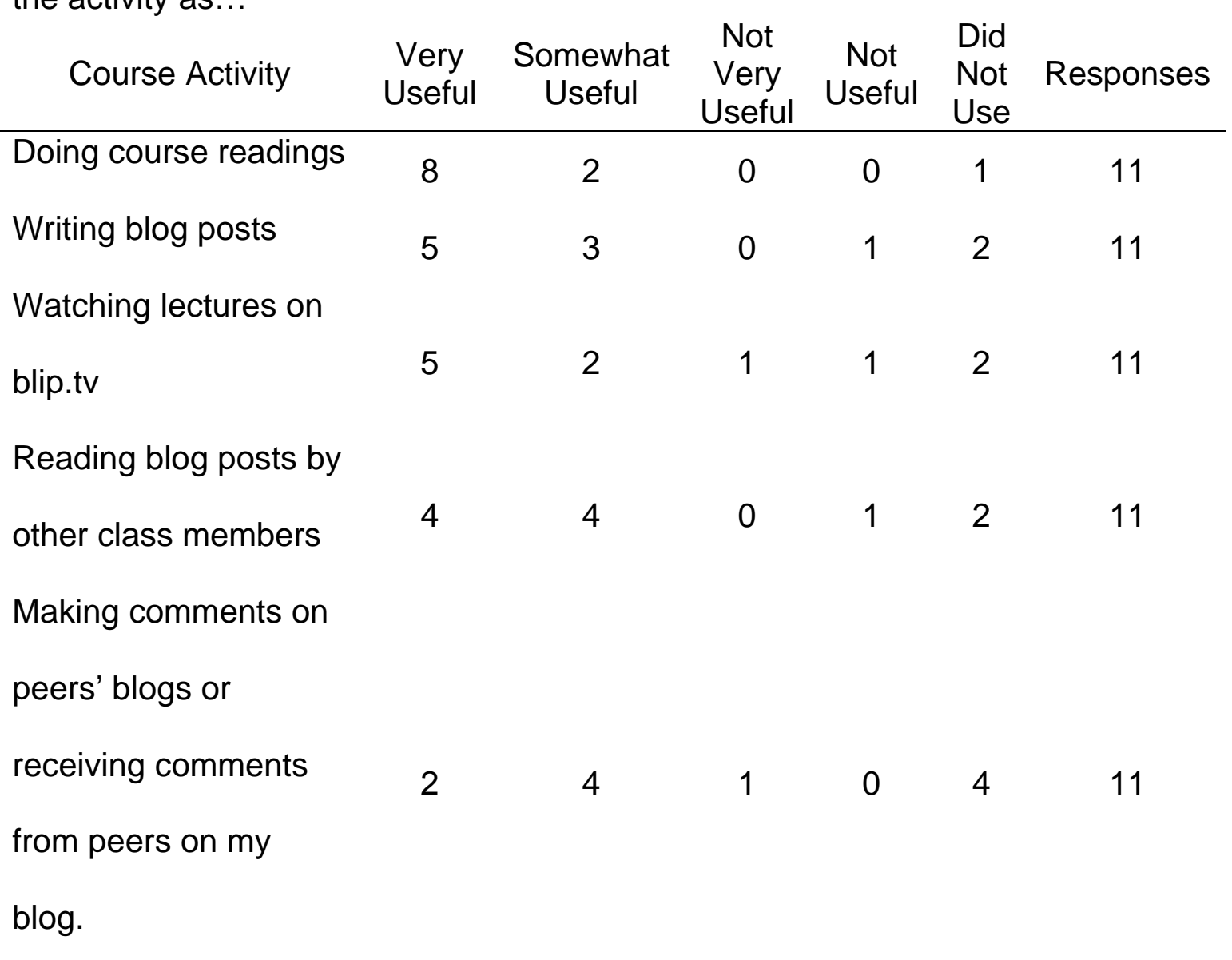


Table 2

Mean responses of learners at a distance about the usefulness of course

aspects.

Mean Response

Course Activity

(lower number $=$

more useful)

Doing course readings

1.2

Writing blog posts

1.67

Watching lectures on blip.tv

1.78

Reading blog posts by other class

members

Making comments on peers' blogs or

receiving comments from peers on my

1.86

blog.

\begin{tabular}{lc}
\hline $\begin{array}{l}\text { Listening to lectures through iTunes or } \\
\text { other source }\end{array}$ & 2 \\
\hline $\begin{array}{l}\text { Communication with the instructor (via } \\
\text { comments on blogs, email, etc.) }\end{array}$ & 2.2 \\
\hline
\end{tabular}


Table 3

Summary of blog posts made by learners at a distance

\begin{tabular}{lll}
$\begin{array}{l}\text { Number of } \\
\text { Participants }\end{array}$ & $\begin{array}{l}\text { Number of posts } \\
\text { made }\end{array}$ \\
\hline 15 & 0 posts \\
5 & 1 post \\
3 & 3 posts \\
1 & 5 posts \\
2 & 6 posts \\
1 & 8 posts \\
& Total: 27 & 39 posts
\end{tabular}


Appendix A

Questionnaire for Learners at a Distance

1. Why did you decide to participate in David Wiley's Introduction to Open Education Class?

2. Approximately how much time (in hours) have you spent on David Wiley's "Introduction to Open Education Course"?

3. How useful were each of the following activities for you?

a. Reading blog posts by other class members

i. Very useful

ii. Somewhat useful

iii. Not very useful

iv. Not useful

v. Did not use at all

b. Doing course readings

i. Very useful

ii. Somewhat useful

iii. Not very useful

iv. Not useful

v. Did not use at all

c. Writing blog posts

i. Very useful

ii. Somewhat useful

iii. Not very useful

iv. Not useful

v. Did not use at all

d. Making comments on peers' blogs or receiving comments from peers on my blog.

i. Very useful

ii. Somewhat useful

iii. Not very useful

iv. Not useful

v. Did not use at all

e. Communication with the instructor (via comments on blogs, email, etc.)

i. Very useful

ii. Somewhat useful

iii. Not very useful

iv. Not useful

v. Did not use at all

f. Watching lectures on blip.tv

i. Very useful

ii. Somewhat useful 
iii. Not very useful

iv. Not useful

v. Did not use at all

g. Listening to lectures through iTunes or other source

i. Very useful

ii. Somewhat useful

iii. Not very useful

iv. Not useful

v. Did not use at all

h. Other (Explain)

i. Very useful

ii. Somewhat useful

iii. Not very useful

iv. Not useful

v. Did not use at all

4. What could have been done to make this course a better experience for you? 
Appendix B

Questionnaire for face-to-face students

1. How did having students participating at a distance affect your experience in the class?
i. Very beneficial
ii. Somewhat beneficial
iii. Made no difference
iv. Somewhat detrimental
v. Very detrimental

2. Why did you answer question \#1 the way you did?

3. Why did you decide to participate in David Wiley's Introduction to Open Education Class?

4. Approximately how much time (in hours) have you spent on David Wiley's "Introduction to Open Education Course"?

5. How useful were each of the following activities for you?

a. Reading blog posts by other class members

i. Very useful

ii. Somewhat useful

iii. Not very useful

iv. Not useful

v. Did not use at all

b. Doing course readings

i. Very useful

ii. Somewhat useful

iii. Not very useful

iv. Not useful

v. Did not use at all

c. Writing blog posts

i. Very useful

ii. Somewhat useful

iii. Not very useful

iv. Not useful

v. Did not use at all

d. Making comments on peers' blogs or receiving comments from peers on my blog.

i. Very useful

ii. Somewhat useful

iii. Not very useful 
iv. Not useful

v. Did not use at all

e. Communication with the instructor (via comments on blogs, email, etc.)

i. Very useful

ii. Somewhat useful

iii. Not very useful

iv. Not useful

v. Did not use at all

f. Watching lectures on blip.tv

i. Very useful

ii. Somewhat useful

iii. Not very useful

iv. Not useful

v. Did not use at all

g. Listening to lectures through iTunes or other source

i. Very useful

ii. Somewhat useful

iii. Not very useful

iv. Not useful

v. Did not use at all

h. Other (Explain)

i. Very useful

ii. Somewhat useful

iii. Not very useful

iv. Not useful

v. Did not use at all

6. What could have been done to make this course a better experience for you? 